ARTICLE

\title{
Design of aqueous redox-enhanced electrochemical capacitors with high specific energies and slow self-discharge
}

Sang-Eun Chun ${ }^{1}$, Brian Evanko², Xingfeng Wang ${ }^{3}$, David Vonlanthen ${ }^{4}$, Xiulei $\mathrm{Ji}^{3}$, Galen D. Stucky ${ }^{2,5} \&$ Shannon W. Boettcher ${ }^{1}$

Electrochemical double-layer capacitors exhibit high power and long cycle life but have low specific energy compared with batteries, limiting applications. Redox-enhanced capacitors increase specific energy by using redox-active electrolytes that are oxidized at the positive electrode and reduced at the negative electrode during charging. Here we report characteristics of several redox electrolytes to illustrate operational/self-discharge mechanisms and the design rules for high performance. We discover a methyl viologen $(\mathrm{MV})$ /bromide electrolyte that delivers a high specific energy of $\sim 14 \mathrm{Wh} \mathrm{kg}^{-1}$ based on the mass of electrodes and electrolyte, without the use of an ion-selective membrane separator. Substituting heptyl viologen for MV increases stability, with no degradation over 20,000 cycles. Self-discharge is low, due to adsorption of the redox couples in the charged state to the activated carbon, and comparable to cells with inert electrolyte. An electrochemical model reproduces experiments and predicts that $30-50 \mathrm{Wh} \mathrm{kg}^{-1}$ is possible with optimization.

\footnotetext{
${ }^{1}$ Department of Chemistry and Biochemistry, University of Oregon, Eugene, Oregon 97403, USA. ${ }^{2}$ Materials Department, University of California, Santa Barbara, California 93106, USA. ${ }^{3}$ Department of Chemistry, Oregon State University, Corvallis, Oregon, 97331, USA. ${ }^{4}$ Department of Physics, University of California, Santa Barbara, California 93106, USA. ${ }^{5}$ Department of Chemistry and Biochemistry, University of California, Santa Barbara, California 93106, USA. Correspondence and requests for materials should be addressed to S.W.B. (email: swb@uoregon.edu).
} 
E lectrochemical double-layer capacitors (EDLCs) store electrical energy at the interface between a solid electrode (for example, high-surface-area-activated carbon) and a liquid electrolyte ${ }^{1-4}$. They are used in commercial applications requiring high power density and long-term cycle stability, for example, in load-leveling and in electric vehicles ${ }^{5,6}$. These characteristics are enabled by a double-layer charging mechanism, which relies on physical ion adsorption/desorption in the Helmholtz layer of the liquid electrolyte and does not require slower solid-state ioninsertion/de-insertion reactions as in, for example, Li-ion batteries ${ }^{1,7,8}$, which also lead to electrode volume change and thus capacity fade with cycling ${ }^{9-11}$. To attain specific energies of $5-10 \mathrm{Wh} \mathrm{kg}^{-1}$, commercial EDLCs require organic electrolytes that operate at high potentials near $3 \mathrm{~V}$. The disadvantages of these electrolytes are (1) low-to-moderate volumetric and gravimetric energy density, (2) high cost, (3) the requirement for high-purity-activated carbon (needed to reduce self-discharge at the high voltages) $)^{12}$ and (4) safety concerns related to flammability ${ }^{4}$. These disadvantages limit applications of EDLCs ${ }^{1,5}$.

One challenge in increasing the energy density of EDLCs is the mass of the electrolyte ${ }^{13,14}$. High-surface-area carbons typically have large pore volumes that fill with inert electrolyte, reducing the cell-level-specific energy ${ }^{13}$. A number of hybrid and pseudocapacitive devices incorporate solid-state or surfaceredox functionality into electrodes to increase the specific energy ${ }^{15-18}$.

In 'redox EDLCs' the inert electrolyte is replaced with a redoxactive one, thereby adding faradaic charge-storage mechanisms to the underlying capacitive ones while ideally maintaining high power and cyclability (Fig. 1) ${ }^{19-22}$. This approach enables the use of aqueous (aq.) electrolytes (where high redox couple solubility results in high capacity) and less-expensive carbons (due to lower operating voltage windows). The disadvantages include the possibility of internal self-discharge via shuttling of mobile redox species, diffusion overvoltage losses and cycling instability due to the intermixing redox couples ${ }^{20,22,23}$. We show that these challenges can be simultaneously mitigated after understanding the fundamental electrochemical processes.

A number of couples have been studied in redox EDLCs including halides, vanadium complexes, copper salts, methylene blue, phenylenediamine, indigo carmine and quinones $19,20,22,24,25$. The performance to date has been low (see Supplementary Table 1 for a comparison of reported work). The most substantial work is by Frackowiak and co-workers ${ }^{4,21}$, who developed aq. potassium iodide (KI) and $\mathrm{VOSO}_{4}$ 'catholyte' and 'anolyte', respectively, separated by a Nafion membrane in two cell compartments. Although specific energy $>20 \mathrm{Wh} \mathrm{kg}^{-1}$ and specific power $>2,000 \mathrm{~W} \mathrm{~kg}^{-1}$ were reported ${ }^{21}$, these metrics are normalized to the mass of the electrodes alone ${ }^{13,26,27}$. While such normalization is common, it is inappropriate for redox EDLCs, where the electrolyte contributes directly to faradaic storage. Accounting for electrolyte (see discussion) reduces performance metrics by at least a factor of 3 . Further, the cost of the Nafion cation-exchange membrane, which is used to prevent self-discharge via redox shuttling, is prohibitive ${ }^{4,21,23}$. Stucky and co-workers studied ${ }^{25}$ a related system containing $\mathrm{KI} / \mathrm{VOSO}_{4}$ electrolyte without an ion-selective separator. They proposed an electrostatic mechanism to account for self-discharge times in the order of $1 \mathrm{~h}$, which was somewhat longer than expected given the separator used.

More-substantial progress has been prevented by the demands on the redox couples needed for the electrolyte. (1) The couples must be soluble at high concentrations, ideally $>1 \mathrm{M}$, to contribute substantially to the capacity. (2) The electron-transfer kinetics must be sufficiently fast to minimize voltage loss during a
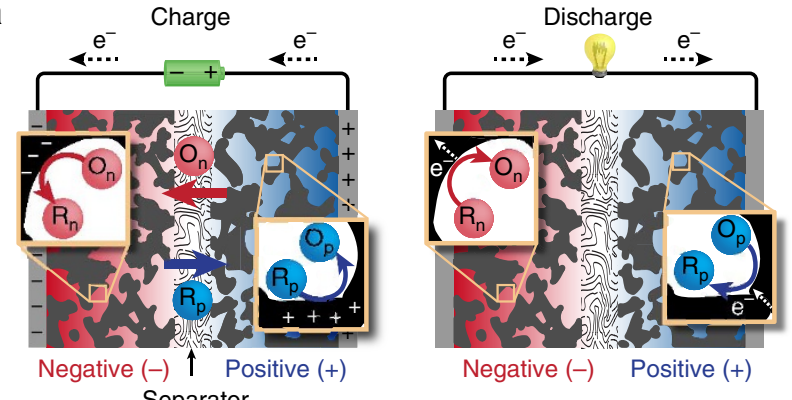

Separator

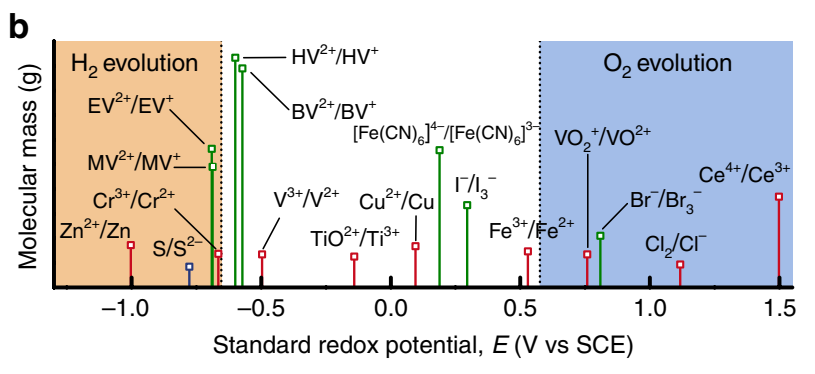

Figure 1 | Microscopic processes and candidate couples for redox EDLCs.

(a) Schematic showing capacitive and faradaic charge-storage processes. The redox couple used at the positive electrode (which is oxidized on charging, and reduced on discharge) is labelled as $\mathrm{O}_{p} / R_{p}$ (catholyte), and the couple used at the negative electrode (which is reduced on charging, and oxidized on discharge) as $O_{n} / R_{n}$ (anolyte). (b) Reduction potentials of the couples considered relative to the thermodynamic stability window of water at neutral $\mathrm{pH}$ (white region). The lines coloured in red, green and blue are for couples stable in acidic (1 M acid), neutral ${ }^{34,37,40,41,67-69}$ and basic $^{70}$ ( $1 \mathrm{M}$ base) conditions, respectively. BV, benzyl viologen; $\mathrm{EV}$, ethyl viologen; $\mathrm{HV}$, heptyl viologen; $\mathrm{MV}$, methyl viologen; $\mathrm{SCE}$, standard calomel electrode.

charge/discharge. (3) The solution behaviour of the charged redox couples must enable slow self-discharge, without the use of expensive ion-selective membranes. (4) During charging, one couple $\left(\mathrm{O}_{p} / \mathrm{R}_{\mathrm{p}}\right)$ must be oxidized at the positive electrode while the other $\left(\mathrm{O}_{\mathrm{n}} / \mathrm{R}_{\mathrm{n}}\right)$ must be reduced at the negative electrode. The relevant redox potentials of the two species should be near the electrolyte decomposition window to maximize the voltage. In water at near-neutral $\mathrm{pH}$, appropriate couples could span $>1.5 \mathrm{~V}$ as the water oxidation and reduction kinetics are slow relative to those of one-electron couples ${ }^{28}$.

Here we report record performance for redox EDLCs using a new electrolyte containing viologen and bromide that was optimized with respect to the above criteria by systematic study of the underlying electrochemical phenomena. A device with $0.4 \mathrm{M}$ potassium bromide $(\mathrm{KBr})$ and $0.1 \mathrm{M}$ heptyl viologen $(\mathrm{HV})$ provides a specific energy of $11 \mathrm{Wh} \mathrm{kg}^{-1}$ at a specific power of $122 \mathrm{~W} \mathrm{~kg}^{-1}$ (normalized to the total mass of both electrodes and electrolyte, with each electrode having a high mass loading of $12.9 \mathrm{mg} \mathrm{cm}^{-2}$ ), and shows negligible fade over 20,000 cycles and slower self-discharge than aq. control EDLCs without redoxactive electrolyte. Using methyl viologen (MV) instead of $\mathrm{HV}$ provides higher energy density $\left(\sim 14 \mathrm{Wh} \mathrm{kg}^{-1}\right)$ due to higher solubility, but also faster self-discharge. The self-discharge mechanisms are studied by comparing the behaviour of redox electrolytes with varying chemical structure and molecular charge. Adsorption of the viologen and $\mathrm{Br}$ redox species to the activated carbon following charging is found to be important, and this effect enables $90 \%$ retention of stored energy after $6 \mathrm{~h}$ at open circuit. In addition to good electrochemical performance, the cells that use aq. electrolyte are simple to prepare under ambient 
conditions and are likely to be safer for application than those using flammable organics ${ }^{4,16}$. The new system is thus appealing as a low-cost aq. capacitor/battery hybrid.

\section{Results}

Cell design and performance analysis. To quantitatively analyse charge-discharge and performance data, two custom cells were designed and built (see Methods section and Supplementary Fig. 1). The first was a T-shaped Swagelok cell that incorporated a reference electrode with the tip placed at the edge of the separator (Supplementary Fig. 1a). This enabled the study of the electrochemical processes at both electrodes simultaneously. Insulated glassy carbon (GC) current collectors were used to avoid background current that might be associated with metallic current collectors. These Swagelok-type cells were flooded with excess electrolyte $(\sim 500 \mu \mathrm{l})$ and thus the specific energy and power were calculated based on the combined 'dry' electrode mass (indicated as $\mathrm{g}_{\mathrm{dry}}$ ) from the discharge data (as is typical and discussed below) $^{29,30}$

We also designed a two-electrode cell with a 'volume-limiting' geometry, where the electrolyte is confined within a machined cavity and sandwiched between two GC plates in contact with the activated carbon (Supplementary Fig. 1b). For the volumelimiting cell, the mass of both electrodes and all electrolyte were used to calculate the specific energy, power and capacity (indicated as $\left.g_{\text {wet }}\right)$. The polycarbonate separator mass $(0.9 \mathrm{mg})$ was ignored as it is only $\sim 1 \%$ of the total cell mass. Performance metrics based on the total 'wet' cell mass are practically relevant, whereas the 'dry' metrics are useful only for comparison to other systems where electrolyte mass has been ignored (Supplementary Table 1).

These well-defined cell geometries enabled rigorous definition and evaluation of performance metrics. The specific capacity at discharge, $Q_{\text {dis }}\left(\mathrm{mAhg}^{-1}\right)$, is defined as

$$
Q_{\text {dis }}=I_{\text {dis }} / m_{\text {cell }} \cdot t_{\text {dis }}
$$

where $I_{\text {dis }}$ is the constant discharge current in $\mathrm{mA}, m_{\text {cell }}$ is the mass of the cell components (as indicated above either 'dry' or 'wet') and $t_{\mathrm{dis}}$ is the discharge time. The specific energy density at discharge, $E_{\mathrm{dis}}\left(\mathrm{Wh} \mathrm{kg}^{-1}\right)$, is calculated by integrating the instantaneous specific power

$$
E_{\mathrm{dis}}=\int_{0}^{t_{\mathrm{dis}}} I_{\mathrm{dis}} / m_{\text {cell }} \cdot V(t) \mathrm{d} t
$$

where $V(t)$ is the time-varying voltage output of the cell. The average specific power, $P_{\text {dis }}\left(\mathrm{W} \mathrm{kg}^{-1}\right)$, is calculated by dividing the energy by the discharge time ${ }^{14,30,31}$

$$
P_{\text {dis }}=E_{\text {dis }} / t_{\text {dis }}
$$

We define the coulombic efficiency, $\eta_{\mathrm{C}}(\delta)$, after a specific selfdischarge period $\delta$ (in min, where the cell is left at open circuit) as

$$
\eta_{\mathrm{C}}(\delta)=Q_{\text {dis }} / Q_{\mathrm{ch}}
$$

where $Q_{\mathrm{ch}}$ is the total charge passed during the charging cycle (analogous to $Q_{\text {dis }}$ defined in equation (1)). We define the energy efficiency $\eta_{\mathrm{E}}(\delta)$ after a specific self-discharge time as

$$
\eta_{\mathrm{E}}(\delta)=E_{\mathrm{dis}} / E_{\mathrm{ch}}
$$

where $E_{\mathrm{ch}}$ is the total energy expended during the charging cycle (analogous to $E_{\mathrm{dis}}$ defined in equation (2)). Finally, we define the energy retention efficiency, $\eta_{\mathrm{R}}(\delta)$, which is the ratio of the energy obtained after a self-discharge period $\delta$ compared with that where $\delta=0$, as

$$
\eta_{\mathrm{R}}(\delta)=E_{\mathrm{dis}}(\delta) / E_{\mathrm{dis}}(0)
$$

Self-discharge was studied by measuring $\eta_{\mathrm{C}}$ and $\eta_{\mathrm{E}}$ as a function of $\delta$ (see Supplementary Fig. 2 and Supplementary Note 1 for details). The cell was first charged to the voltage indicated at $0.5 \mathrm{Ag}_{\mathrm{dry}}^{-1}$. We use the 'half-life' of the specific energy $t_{1 / 2 \cdot E_{\max }}$, where $\eta_{\mathrm{R}}\left(t_{1 / 2 \cdot E_{\max }}\right)=0.5$ as well as $\eta_{\mathrm{R}}(6 \mathrm{~h})$ to compare the different self-discharge rates of the cells. When $t_{1 / 2 \cdot E_{\max }}$ was longer than the test duration $(6 \mathrm{~h})$, the experimental $\eta_{\mathrm{R}}$ data was fit to a linear decay to estimate $t_{1 / 2 \cdot E_{\max }}$.

Redox-active electrolytes for the positive electrode. Redox species at the positive electrode are reduced during discharge $\left(\mathrm{O}_{\mathrm{p}}+\mathrm{e}^{-} \rightarrow \mathrm{R}_{\mathrm{p}}\right)$ and thus referred to as the 'catholyte'. The catholyte should have a reduction potential near, or slightly more positive than, the oxygen evolution potential to maximize energy density. The halogens iodide and bromide are promising as they are inexpensive and highly soluble $(>1 \mathrm{M})^{32,33}$. The aq. reduction potential of iodine $\left(E_{\mathrm{I}^{-} / \mathrm{I}^{-}}^{\circ}=0.3 \mathrm{~V}\right.$ versus the standard calomel electrode (SCE)) is within the water stability window, while that of bromine $\left(E_{\mathrm{Br}_{3}^{-}}^{\circ} / \mathrm{Br}^{-}=0.81 \mathrm{~V}\right.$ versus SCE$)$ is above the thermodynamic oxygen evolution potential at $\mathrm{pH} 7(0.58 \mathrm{~V}$ versus $\mathrm{SCE})^{34}$

Figure 2a shows the galvanostatic cycling profiles of candidate catholytes tested in a three-electrode Swagelok cell. For 1M KI, the positive electrode potential narrowly varied between $0.02 \mathrm{~V}$ and $0.19 \mathrm{~V}$ versus SCE, indicating oxidation of $\mathrm{I}^{-}$to $\mathrm{I}_{3}^{-}$(the difference between the observed plateau potential and $E_{\mathrm{I}_{3}}^{\circ} / \mathrm{I}^{-}=$ $0.3 \mathrm{~V}$ versus SCE is discussed below $)^{34}$. The negative electrode potential varied linearly with charge between $0.02 \mathrm{~V}$ and $-0.81 \mathrm{~V}$ versus SCE, indicating a double-layer charging mechanism with inert $\mathrm{K}^{+}$.

For $1 \mathrm{M} \mathrm{KBr}$ electrolyte, the positive electrode shows two distinct charging regimes. For the first $60 \mathrm{~s}$, the electrode potential depends linearly on the charge, indicating capacitive charging with $\mathrm{Br}^{-}$in the double layer. For the next $60 \mathrm{~s}$, the potential increase slows and plateaus at $\sim 0.7 \mathrm{~V}$ versus SCE, indicating oxidation of $\mathrm{Br}^{-}$to $\mathrm{Br}_{3}^{-}$(ref. 34). The negative electrode shows purely capacitive charging. The high redox potential of $\mathrm{Br}^{-} / \mathrm{Br}_{3}^{-}$ is advantageous for increasing energy density.

EDLC self-discharge is commonly studied by monitoring the potential decay at open circuit ${ }^{35,36}$. However, because the charge is not linear with potential for redox EDLCs, we measured energy retention $\eta_{\mathrm{R}}$ by complete discharge at each time point in Fig. 2c. The self-discharge profiles of $\mathrm{KI}$ and $\mathrm{KBr}$ show $\eta_{\mathrm{R}}$ of $76 \%$ and $43 \%$ after $6 \mathrm{~h}$, respectively (Fig. $2 \mathrm{c}$ ). Remarkably, the self-discharge rate of the KI cell is slower than that of the control potassium sulfate $\left(\mathrm{K}_{2} \mathrm{SO}_{4}\right)$ cell when also charged to $1 \mathrm{~V}$ $\left(\eta_{\mathrm{R}}=67 \%\right.$ after $\left.6 \mathrm{~h}\right)$. Given the lack of an ion-selective membrane, the slow self-discharge of the halogen cells is unexpected. After charging the KI cell, a large concentration gradient of $\mathrm{I}_{3}^{-}$and $\mathrm{I}^{-}$between the positive and negative electrode is present that would normally be expected to drive diffusive transport across the cell resulting in fast self-discharge.

One hypothesis that might explain the remarkably slow selfdischarge is that the negatively charged oxidation products $\mathrm{I}_{3}^{-}$ or $\mathrm{Br}_{3}^{-}$are electrostatically held in the double layer of the positively charged activated carbon electrode. To test this, we fabricated new cells with potassium ferrocyanide $\left(\mathrm{K}_{4} \mathrm{Fe}(\mathrm{CN})_{6}\right)$ and tris $\left(2,2^{\prime}\right.$-bipyridyl $)$ dichloro-cobalt $\quad\left(\mathrm{Co}(\text { bpy })_{3} \mathrm{Cl}_{2}\right)$ redox-active electrolytes. Both couples have reduction potentials similar to $\mathrm{I}_{3}^{-} / \mathrm{I}^{-}$and fast kinetics (Supplementary Figs 4 and 5). $\mathrm{Co}(\mathrm{bpy})_{3}^{2+13+}$ has a positive charge, and thus would be expected to be expelled from the double layer at the positive electrode (where it is oxidized) and subsequently reduced after diffusing to the negative electrode, thus increasing the self-discharge rate. $\mathrm{Fe}(\mathrm{CN})_{6}^{4-13-}$ has a negative charge, like $\mathrm{I}_{3}^{-} / \mathrm{I}^{-}$, and thus might 
a

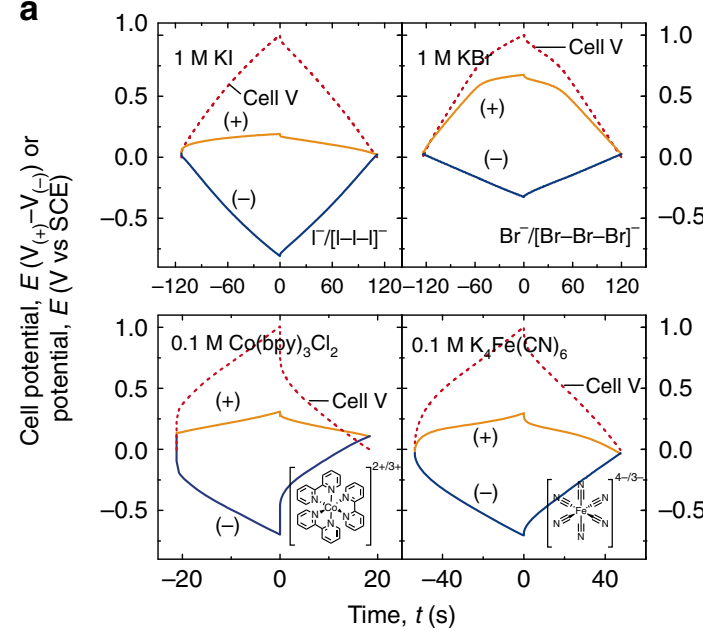

b
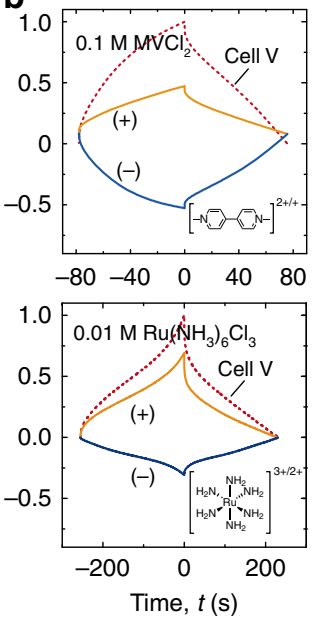

c

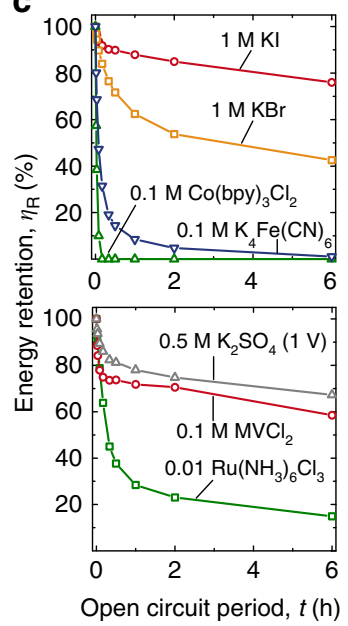

Figure 2 | Electrochemical characterization of cells with a single redox couple. The galvanostatic charge/discharge profiles (dashed red lines) of the candidate redox couples are shown for (a) the positive electrode (solid orange) and (b) the negative electrode (solid blue), respectively, referenced to the centrally placed SCE. The cells were charged/discharged at a rate of $1 \mathrm{Ag}^{-1}(+)$ electrode (normalized to the mass of the positive electrode only, because the negative electrode mass was varied to accommodate couples with different redox potentials) to a total cell voltage of $1 \mathrm{~V}$. (c) Energy retention $\eta_{\mathrm{R}}$ for the cells in $\mathbf{a}, \mathbf{b}$. Each data point was collected by charging the cell, allowing it to sit at open circuit for a given time, then discharging the cell completely. In $\mathbf{a}$, the slope of the potential-time curve for the negative electrode is smaller for the $\mathrm{KBr}$ cell than for the $\mathrm{KI}$ cell, because the negative electrode had three times the mass of the positive electrode so that the positive electrode was able to reach the $\mathrm{Br}^{-}$oxidation potential with a total cell potential of $1 \mathrm{~V}$, which was not possible with a symmetric cell (as in Supplementary Fig. 3).

also show retarded self-discharge if electrostatic effects play the dominate role.

$\mathrm{K}_{4} \mathrm{Fe}(\mathrm{CN})_{6}$ and $\mathrm{Co}(\mathrm{bpy})_{3} \mathrm{Cl}_{2}$ cells show galvanostatic charging behaviour at the positive electrode similar to the KI cell with the electrode potential pinned near the standard potential of the couple (Fig. 2a). The negative electrodes show capacitive (linear potential-time) response on charging. On discharging, an additional potential loss associated with the low ionic conductivity of the $0.1 \mathrm{M}$ redox-active electrolytes is measured. The $\mathrm{Co}(\text { bpy })_{3} \mathrm{Cl}_{2}$ and $\mathrm{K}_{4} \mathrm{Fe}(\mathrm{CN})_{6}$ cells have $89.5 \%$ and $90.8 \%$ coulombic efficiency, respectively-lower than the $99.9 \%$ and 98.8\% measured for the $\mathrm{KI}$ and $\mathrm{KBr}$ cells, respectively. The $\mathrm{Co}$ (bpy) $)_{3} \mathrm{Cl}_{2}$ cell loses half of its energy in $1 \mathrm{~min}$, while for the $\mathrm{K}_{4} \mathrm{Fe}(\mathrm{CN})_{6}$ cell this takes $5 \mathrm{~min}$ (Fig. 2c). This data is consistent with electrostatics contributing to the self-discharge in the case of $\mathrm{Co}(\mathrm{bpy})_{3}^{2+13+}$ and retarding it in the case of $\mathrm{Fe}(\mathrm{CN})_{6}^{4-13-}$, and for the halides. However, despite the large negative charge of $\mathrm{Fe}(\mathrm{CN})_{6}^{4-13-}$, its self-discharge rate is still roughly 100 times that of $\mathrm{I}_{3}^{-} / \mathrm{I}^{-}$. The retarded self-discharge for the halides cannot be explained purely by electrostatics.

Another mechanism to explain the slow self-discharge is physical adsorption of the oxidized species within the activated carbon surface preventing cross diffusion. Halides are known to adsorb on carbon electrodes ${ }^{37-39}$ and we confirmed the strong adsorption of $\mathrm{Br}_{3}^{-}$using ultraviolet-visible spectroscopy. In contrast, $\mathrm{Br}^{-}, \mathrm{Fe}(\mathrm{CN})_{6}^{4-}$ and $\mathrm{Fe}(\mathrm{CN})_{6}^{3-}$ do not adsorb (see Supplementary Note 2 and Supplementary Fig. 6). Further, the observed potential plateau for both the KBr and KI cells (Fig. 2a) is $\sim 0.1 \mathrm{~V}$ less positive than the standard potential of the respective couples. This is consistent with specific adsorption stabilizing the oxidized halide, shifting the formal potential within the activated carbon negative of the standard potential. These results show that physical adsorption is the primary mechanism preventing self-discharge and electrostatic effects are secondary.

Redox-active electrolytes for the negative electrode. Redox couples for the negative electrode $\left(\mathrm{O}_{n} / \mathrm{R}_{n}\right)$ should have standard potentials near the hydrogen evolution potential, as well as high solubility and solution compatibility with the catholyte. Based on the findings discussed above, $\mathrm{O}_{n} / \mathrm{R}_{n}$ should have a positive charge and physically adsorb on activated carbon following charging to prevent self-discharge.

Viologen dications $\left(4,4^{\prime}\right.$-bipyridinium compounds) are positively charged, highly soluble redox couples, with formal potentials negative of the hydrogen potential and fast, reversible, kinetics ${ }^{40-45}$. $\quad \mathrm{MVCl}_{2} \quad\left(1,1^{\prime}\right.$-Dimethyl-4,4'-bipyridinium dichloride) was studied first due to its negative potential $\left(E^{\mathrm{O}}=-0.69 \mathrm{~V}\right.$ versus $\left.\mathrm{SCE}\right)$, commercial availability and low cost $\left(<\$ 5 \mathrm{~kg}^{-1} \text { in bulk, used for agriculture }\right)^{43,46,47}$. Being a nearly co-planar $\pi-\pi$ conjugated ring system, $\mathrm{MVCl}_{2}$ also adsorbs on activated carbon surfaces ${ }^{48}$. Stronger adsorption is expected after reduction of $\mathrm{MV}^{2+}$ to $\mathrm{MV}^{+}$due to decreased charge density and increased co-planarity of the two adjacent rings.

To study the viologen electrochemistry in the absence of a redox-active electrolyte at the positive electrode, a $4: 1$ mass ratio for the positive/negative electrode was used. During galvanostatic charging, the positive electrode potential varies nearly linearly with time, while the negative electrode potential curves with time/ charge near $\sim-0.5 \mathrm{~V}$ versus SCE (Fig. $2 \mathrm{~b}$ ), consistent with the reduction of $\mathrm{MV}^{2+}$ to $\mathrm{MV}^{+}$(Supplementary Fig. 7). The selfdischarge rate of the $\mathrm{MVCl}_{2}$ electrolyte was measured (Fig. 3c) and found comparable to that of the EDLC with $0.5 \mathrm{M} \mathrm{K}_{2} \mathrm{SO}_{4}$, suggesting that $\mathrm{MV}^{2}+/ \mathrm{MV}^{+}$does not contribute substantially to self-discharge via redox shuttling.

To understand the self-discharge processes, a ruthenium hexamine dichloride electrolyte was also studied (Fig. 2b). $\mathrm{Ru}\left(\mathrm{NH}_{3}\right)_{6}^{3+} / \mathrm{Ru}\left(\mathrm{NH}_{3}\right)_{6}^{2+}$ is cationic, like $\mathrm{MV}^{2+} / \mathrm{MV}^{+}$, but is unlikely to specifically adsorb on the activated carbon surface because of its near-spherical molecular shape. The hexaammineruthenium (III) chloride $\left(\mathrm{Ru}\left(\mathrm{NH}_{3}\right)_{6} \mathrm{Cl}_{3}\right)$ cell shows double-layer charging with $\mathrm{Cl}^{-}$on the positive electrode and some faradaic charging on the negative electrode with a slight plateau near $-0.2 \mathrm{~V}$ consistent with the reduction of $\left.\mathrm{Ru}_{(\mathrm{NH}}\right)_{6}^{3+}$ $\left(E^{\mathrm{o}} \sim-0.14 \mathrm{~V} \text { versus SCE, Supplementary Fig. } 8\right)^{49}$. The selfdischarge rate (Fig. 2c), however, is significantly faster for 
$\mathrm{Ru}\left(\mathrm{NH}_{3}\right)_{6} \mathrm{Cl}_{3}$ than for $\mathrm{MVCl}_{2}$, providing further evidence that electrostatic effects are not sufficient to prevent self-discharge and that $\mathrm{MV}^{+}$, like the oxidized halides, adsorbs on the carbon electrode $^{50}$. Ultraviolet-visible spectroscopy supports this mechanism, showing weak adsorption of $\mathrm{MV}^{2+}$ and strong adsorption of $\mathrm{MV}^{+}$(see Supplementary Note 2 and Supplementary Fig. 6).

Combined electrolyte systems. For high performance, the redoxactive electrolytes for the positive and negative electrodes must be combined. All species in both redox states $\left(\mathrm{O}_{n}, R_{n}, O_{p}\right.$ and $\left.R_{p}\right)$ should be stable in the same electrolyte to reduce manufacturing complexity and demands on the separator. We first studied $\mathrm{MVCl}_{2} / \mathrm{KI}$, which was stable in the uncharged state but formed $\mathrm{MV}^{+}-\mathrm{I}^{-}$precipitate on charging (Supplementary Fig. 9) leading to irreversible capacity loss ${ }^{41,51}$. In contrast, $\mathrm{MVCl}_{2} / \mathrm{KBr}$ solutions showed highly reversible redox behaviour of both redox ions in analytical voltammetry cells (Supplementary Fig. 10). $\mathrm{Br}^{-}$benefits from a more-positive oxidation potential compared with $\mathrm{I}^{-}$, thus providing increased specific energy, but is more reactive/corrosive.

Cells with $1 \mathrm{M} \mathrm{KBr} / 0.1 \mathrm{M} \mathrm{MVCl}_{2}$ electrolyte were tested by voltammetry and galvanostatic cycling to probe the charging mechanism (Fig. 3a,c). Voltammograms collected with a $1 \mathrm{~V}$ window are rectangular, indicating capacitive charging at both electrodes. As the $\mathrm{Br} / \mathrm{MV}$ cell was cycled beyond $1 \mathrm{~V}$, current peaks were observed at the positive and negative electrodes corresponding to $\mathrm{Br}^{-}$oxidation to $\mathrm{Br}_{3}^{-}$and $\mathrm{MV}^{2+}$ reduction to $\mathrm{MV}^{+}$, respectively, (Fig. 3a).

Figure $3 \mathrm{c}$ shows the galvanostatic charging of the same cells to different total cell voltages. At both the positive and negative electrodes (orange and blue traces, respectively) an initial capacitive (linear) voltage-time response is observed followed by a faradaic response as the electrode potential approaches the reduction potential of the couple.

Figure $3 e, f$ shows that the self-discharge rate for the $1 \mathrm{M} \mathrm{KBr} /$ $0.1 \mathrm{M} \mathrm{MVCl}_{2}$ cell charged to $1.4 \mathrm{~V}\left(t_{1 / 2 \cdot E_{\max }}=170 \mathrm{~min}\right)$ is similar to the commercial Cellergy capacitor $\left(t_{1 / 2 \cdot E_{\max }}=140 \mathrm{~min}\right)$, but still faster than the commercial non-aq. Maxwell cell and the KI or $\mathrm{KBr}$ aq. cells $\left(t_{1 / 2 \cdot E_{\max }}>6 \mathrm{~h}\right)$, suggesting that $\mathrm{MV}^{2+} / \mathrm{MV}^{+}$ may contribute to self-discharge under these conditions.

To improve the self-discharge (and cycle stability as discussed below), we explored different viologens. HV forms a strongly bonded solid on electrodes following its reduction in aq. solution in the presence of $\mathrm{Br}^{-}$or $\mathrm{I}^{-}$, as evidenced by voltammetry and ultraviolet-visible spectroscopy ${ }^{42,43,52-55}$. This adsorption/ insolubility could be useful to impede internal shunting as long as the adsorption process is reversible. We tested $\mathrm{HVBr}_{2}$ ( $1,1^{\prime}$-Diheptyl-4,4'-bipyridinium dibromide; the chloride salt is not commercially available) in cells in an identical manner as described above for the $\mathrm{KBr} / \mathrm{MVCl}_{2}$ cells. The results are similar with the exception that $\mathrm{HV}^{2+}$ has a more-positive reduction potential $\left(E^{\mathrm{O}}=-0.60 \mathrm{~V}\right.$ versus $\left.\mathrm{SCE}\right)$ than $\mathrm{MV}^{2+}$ leading to a lower plateau voltage ${ }^{41,43}$. The galvanostatic charge-discharge curves (Fig. 3d) also show evidence of higher ionic resistance due to lower electrolyte concentration.

The self-discharge rate of the $\mathrm{HVBr}_{2}$ electrolyte is substantially lower than that for $\mathrm{KBr} / \mathrm{MVCl}_{2}$. Further, the self-discharge rate for $\mathrm{HVBr}_{2}$ decreases as the charging voltage is increased, whereas it increases for $\mathrm{KBr} / \mathrm{MVCl}_{2}$ with voltage. This data is consistent with the strong adsorption/precipitation of the $\mathrm{HV}^{+}$onto the activated carbon following charging (Supplementary Fig. 10). The weaker-adsorbing $\mathrm{MV}^{+}$apparently contributes to self-discharge when large concentrations accumulate at high states of charge. The formation of $\mathrm{HV}^{+}$films was confirmed by voltammetry and
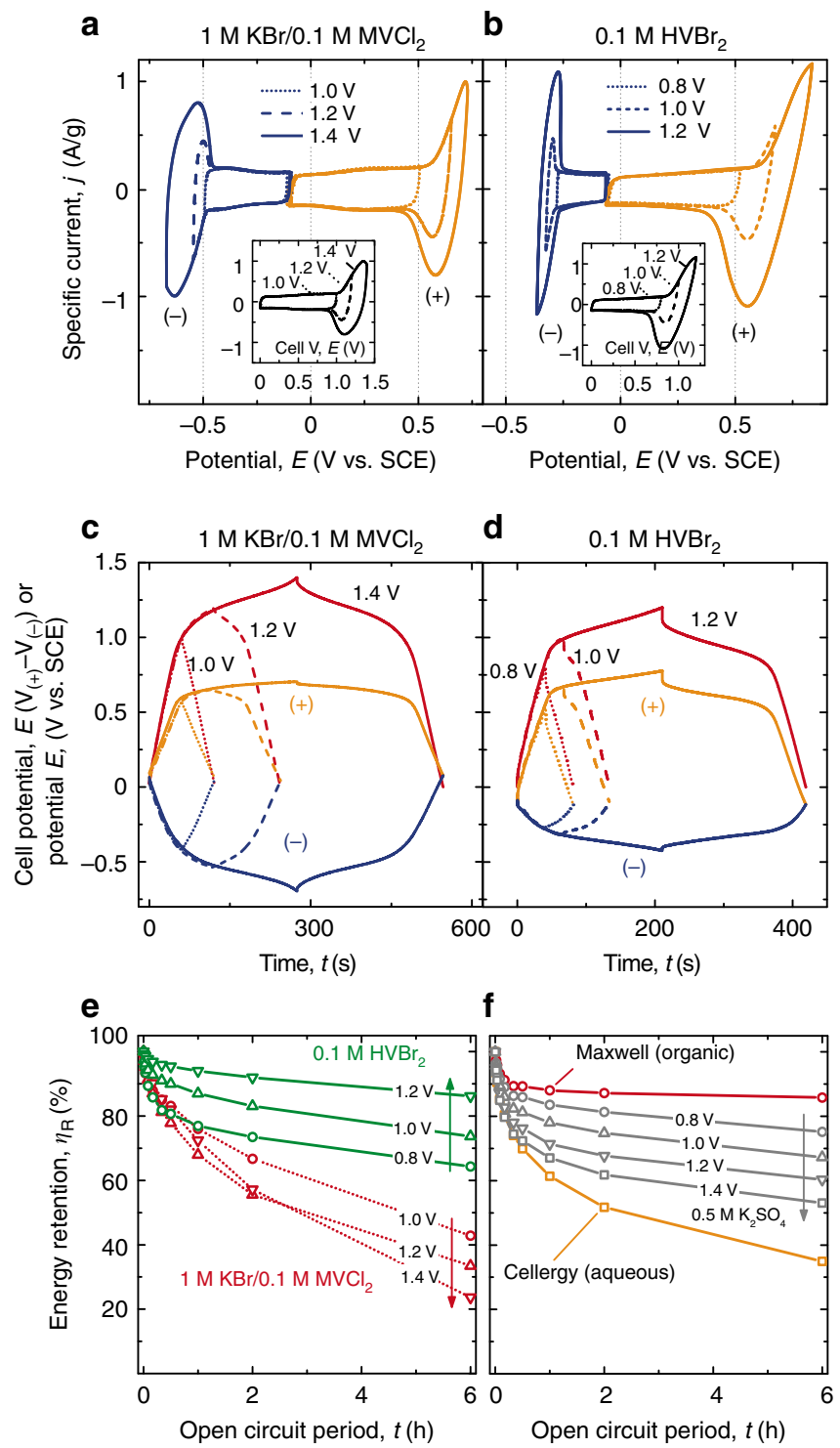

Figure 3 | Electrochemical characterization of cells with combined

electrolytes. a,b show voltammograms for the complete cell collected at $5 \mathrm{mVs}^{-1}$ (inset) with the voltages for the positive (orange) and negative (blue) electrodes separately recorded. c,d show the galvanostatic charge/ discharge profiles at $0.5 \mathrm{Agdry}^{-1}$ to a total cell potential between 0.8 and $1.4 \mathrm{~V}$. e shows the energy retention $\eta_{\mathrm{R}}$ for the cells with redox-active electrolyte, demonstrating substantial differences in the self-discharge rate between cells with $\mathrm{HV}$ and those with MV. $\mathbf{f}$ shows $\eta_{\mathrm{R}}$ for the control cells tested with inert electrolyte and commercial EDLCs (See Supplementary Note 3, Supplementary Fig. 11 and Supplementary Table 2).

visual observation on a GC electrode in an analytical half-cell (Supplementary Fig. 10). In addition, the thin $\mathrm{HVBr}_{2}$ layer formed on the electrode might block impurity transport, which provides a significant self-discharge path in aq EDLCs with inert electrolyte ${ }^{35}$. The adsorption/precipitation process was completely reversible with the $\mathrm{HVBr}_{2}$ showing nearly $100 \%$ coulombic efficiency. The concept of using an immobilized redox-ion on the electrode surface to limit self-discharge was proposed recently using the $\mathrm{Cu}^{2+} / \mathrm{Cu}^{0}$ couple, but this requires acidic conditions, is susceptible to dendrite formation, and no complementary couple was used at the opposite electrode ${ }^{23}$. 
Table 1 shows the specific capacity and energy of the redoxenhanced cells evaluated with galvanostatic cycling. These data were collected in the Swagelok cell with excess electrolyte and therefore the performance metrics were normalized to the mass of the electrodes only and do not include the electrolyte (as is typical). The dramatic effect of the added faradaic reaction is apparent; the $1 \mathrm{M} \mathrm{KBr} / 0.1 \mathrm{M} \mathrm{MVCl}_{2}$ cell at $1.4 \mathrm{~V}$ (driving faradaic + capacitive charging) stores over four times more charge than at $1.0 \mathrm{~V}$ (capacitive charging only), and has eight times larger specific energy.

Performance quantification and optimization. To increase energy density and minimize ionic resistance, higher redox-active electrolyte concentrations are needed. Further, the practical specific energy and power must be evaluated based on both electrode and electrolyte mass ${ }^{13} . \mathrm{MVCl}_{2}$ is highly soluble in water $(>2 \mathrm{M})$, whereas the $\mathrm{HVBr}_{2}$ solubility is $<0.2 \mathrm{M}$ (ref. 56 ). $1.0 \mathrm{M} \mathrm{KBr}$ / $0.5 \mathrm{M} \mathrm{MVCl}_{2}$ and $0.4 \mathrm{M} \mathrm{KBr} / 0.1 \mathrm{M} \mathrm{HVBr}_{2}$ were tested in the twoelectrode 'volume-limiting' cell, which accommodates a precise quantity of electrolyte. Thin polycarbonate film $(9 \mu \mathrm{m})$ instead of Whatman paper $(180 \mu \mathrm{m})$ was used as a separator to minimize excess electrolyte. The $\mathrm{KBr} / \mathrm{HVBr}_{2}$ cell with a polycarbonate separator exhibits $t_{1 / 2 \cdot E_{\max }}=370 \mathrm{~min}$, significantly faster selfdischarge than with Whatman paper $\left(t_{1 / 2 \cdot E_{\max }}=2,600 \mathrm{~min}\right.$, Supplementary Fig. 12), which is expected since the thinner separator provides a shorter diffusion pathway. Nonetheless, the self-discharge in the $\mathrm{Br} / \mathrm{HV}$ cells is slower than control EDLCs using the same polycarbonate film $\left(t_{1 / 2 \cdot E_{\max }}=230 \mathrm{~min}\right)$. Further, the self-discharge rate decreased after prolonged cycling for $\mathrm{HVBr}_{2}$. After 1,000 galvanostatic charge/discharge cycles, $\eta_{\mathrm{R}}(6 \mathrm{~h})=87 \%$ and $t_{1 / 2 \cdot E_{\max }}=1,770 \mathrm{~min}$. After 2,000 cycles, it increased to $\eta_{\mathrm{R}}(6 \mathrm{~h})=93 \%$ and $t_{1 / 2 \cdot E_{\max }}=3,800 \mathrm{~min}$ (Supplementary Fig. 13). This excellent self-discharge rate is an important figure of merit as a practical energy storage device.

Performance parameters measured from galvanostatic cycling at $0.5 \mathrm{Agdry}_{\text {dry }}^{-1}$ in volume-limiting cells are given in Table 2. The mass-based metrics are reported normalized to both the total active-material mass (electrodes + electrolyte) and, in parentheses, the electrode mass only. The specific energies achieved for the $\mathrm{KBr} / \mathrm{MVCl}_{2}$ system $\left(\sim 14 \mathrm{Wh} \mathrm{kg}_{\text {wet }}^{-1}\right.$ or $\left.51 \mathrm{Wh} \mathrm{kg}_{\text {dry }}^{-1}, \quad 16.8 \mathrm{mWh} \mathrm{cm}^{-3}\right)$ and $\mathrm{KBr}^{-1} \mathrm{HVBr}_{2}$ system

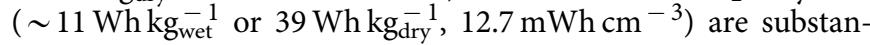
tially larger than all previous reports of aq. redox EDLCs (see Supplementary Table 1$)$. A concentrated $\mathrm{MV}^{2}+$ cell $(1 \mathrm{M} \mathrm{KBr} /$ $1 \mathrm{M} \mathrm{MVCl}_{2}$ ) was assembled to increase the energy density, but the cell showed lower coulombic efficiency with $\eta_{\mathrm{C}}(0) \sim 90 \%$ (Supplementary Fig. 14).

We measured the relationship between energy and power, and compared the performance to control aq. $\mathrm{K}_{2} \mathrm{SO}_{4}$ devices and published reference data on a Ragone plot (Fig. 4 and Supplementary Fig. 15). The metrics estimated for both devices are promising as they fill a gap between high-power batteries and traditional EDLCs using simple, potentially low-cost, aq. chemistry. Additional optimization and cell engineering (discussed below) would further improve both power (reduced internal resistance) and specific energy.

To study degradation/fading, cells were cycled at 0.5 and $2.5 \mathrm{Ag}_{\text {dry }}^{-1}$ (Fig. 4 inset). The energy density of the $\mathrm{KBr} / \mathrm{MVCl}_{2}$ cell fades over the course of several hundred cycles. This degradation is likely due to irreversible polymerization of $\mathrm{MV}^{+}$ in the aq. electrolyte ${ }^{41,43}$. In comparison, the $\mathrm{KBr} / \mathrm{HVBr}_{2}$ cell shows no fading over 2,000 cycles $\left(0.5 \mathrm{Ag}_{\text {dry }}^{-1}\right)$ and 20,000 cycles $\left(2.5 \mathrm{Ag}_{\mathrm{dry}}^{-1}\right)$. The specific energy and power are largely limited by the lower solubility of $\mathrm{HV}^{2}+$. There are hundreds of viologen derivatives that can be synthesized-an appropriate combination of solubility and stability can likely be found ${ }^{43,57,58}$.

\section{Discussion}

There has been previous work aimed at enhancing conventional EDLCs using faradaic charging from soluble redox species (see Supplementary Table 1). Previous cells often rely on a single redox process at one electrode coupled with capacitive charging at the other, but this capacity mismatch lowers cell-level performance $20,22,59-61$. Balancing the capacity with different redox

Table 1 | Performance metrics obtained from data shown in Fig. 3 collected using Swagelok cells.

\begin{tabular}{|c|c|c|c|c|c|c|}
\hline$\overline{\text { Specific capacity*, } Q_{\text {dis }}\left(m A h g_{\text {dry }}^{-1}\right)}$ & 9.2 & 18.0 & 37.9 & 4.0 & 9.0 & 32.1 \\
\hline Coulombic efficiency, $\eta_{C}(0)$ & $98.8 \%$ & $99.0 \%$ & $98.8 \%$ & $99.9 \%$ & $99.4 \%$ & $99.9 \%$ \\
\hline Energy efficiency, $\eta_{\mathrm{E}}(0)$ & $99 \%$ & $92 \%$ & $92 \%$ & $63 \%$ & $80 \%$ & $87 \%$ \\
\hline Energy retention, $\eta_{\mathrm{R}}(6 \mathrm{~h})$ & $43 \%$ & $33 \%$ & $24 \%$ & $64 \%$ & $64 \%$ & $86 \%$ \\
\hline
\end{tabular}

Table 2 | Performance metrics for electrolyte-volume-limited cells.

Redox-active species

Electrode masses ( $\mathrm{mg}$ ) (including binder and conductive additive)

Electrolyte mass (mg)

$m_{\text {electrode }} / m_{\text {electrolyte }}$

Operating voltage $(\mathrm{V})$

Specific capacity*, $Q_{\text {dis }}$

Specific energy ${ }^{\star}, E_{\text {dis }}$

Power density ${ }^{\star}, P_{\text {dis }}$
$1 \mathrm{M} \mathrm{KBr} / 0.5 \mathrm{M} \mathrm{MVCl}_{2}$

$0.4 \mathrm{M} \mathrm{KBr} / 0.1 \mathrm{M} \mathrm{HVBr}_{2}$

Cathode: $20.7 \mathrm{mg}$; Anode: $20.6 \mathrm{mg}$

$110.1 \mathrm{mg}$

$1: 2.69 \pm 0.02$

$1.4 \mathrm{~V}$

$13.3 \mathrm{mAhg}_{\text {wet }}^{-1}\left(48.8 \mathrm{mAh}_{\mathrm{dry}}^{-1}\right)$

13.9 Wh kg wet $^{-1}$ (51.0 Wh kg dry $)$

$142 \mathrm{~W} \mathrm{~kg}_{\text {wet }}^{-1}\left(521 \mathrm{~W} \mathrm{~kg}_{\text {dry }}^{-1}\right.$ )
Cathode: $10.0 \mathrm{mg}$; Anode: $10.0 \mathrm{mg}$ $53.1 \mathrm{mg}$

$1: 2.67 \pm 0.07$

$1.2 \mathrm{~V}$

$12.1 \mathrm{mAh} \mathrm{g}_{\text {wet }}^{-1}\left(44.0 \mathrm{mAh} \mathrm{g}_{\text {dry }}^{-1}\right.$ )

10.8 Wh kg Wet $^{-1}$ (39.3 Wh kg-1)

$122 \mathrm{~W} \mathrm{~kg}_{\text {wet }}^{-1}$ ( $447 \mathrm{~W} \mathrm{~kg}_{\text {dry }}^{-1}$ )

${ }^{\star}$ The performance data were normalized by both electrodes and electrolyte mass and, in parenthesis, by electrode mass only. 
species at each electrode has been demonstrated, but the potential difference between the couples has been small, leading to low specific energy when electrolyte weight is considered, and the cells have required ion-selective Nafion separators ${ }^{21}$. The $\mathrm{Br} /$ viologen cell in this work was designed and optimized to achieve high energy density considering all active components (electrode and electrolyte) and simultaneously shows better specific energy and self-discharge behaviour than previous redox-enhanced EDLCs.

It is also useful to compare these redox EDLCs to flow batteries ${ }^{37,62}$. While both store charge through oxidation and reduction of soluble couples, the underlying design principles and applications are different. A flow battery can use relatively expensive separators, because the separator is a small component of the total flow-battery system cost (that includes pumps, automated controls and storage tanks). In EDLCs, the separators must be inexpensive because they are identical in size to the largearea-activated carbon electrodes. The redox couples in the catholyte and anolyte must also be stable together, as it would be practically challenging in a redox EDLC to prevent crossover by sealing the catholyte from the anolyte compartments. Redox EDLCs require careful control and optimization of the carbon porosity, as the carbon serves as the reservoir for the redox electrolyte and also contributes substantial capacitive energy storage capability. Practically, flow batteries find application in grid-scale energy storage, whereas redox EDLCs are targeted for high-power applications, for example, in transportation.

To better understand redox EDLCs and predict performance limits, we developed an electrochemical model. At every state of charge, the capacitive and faradaic charge passed to (or from) one electrode is a function of the electrode potential $E_{\mathrm{el}}$. The capacitive contribution to the charge $q_{\text {cap }}$ is

$$
q_{\mathrm{cap}}=C_{\mathrm{sp}} \cdot m_{\mathrm{el}} \cdot\left|E_{\mathrm{el}}-E_{\mathrm{el}, 0}\right|
$$

where $C_{\mathrm{sp}}$ is the specific electrode capacitance, $m_{\mathrm{el}}$ is the electrode mass and $E_{\mathrm{el}, 0}$ is the electrode potential in the discharged state.

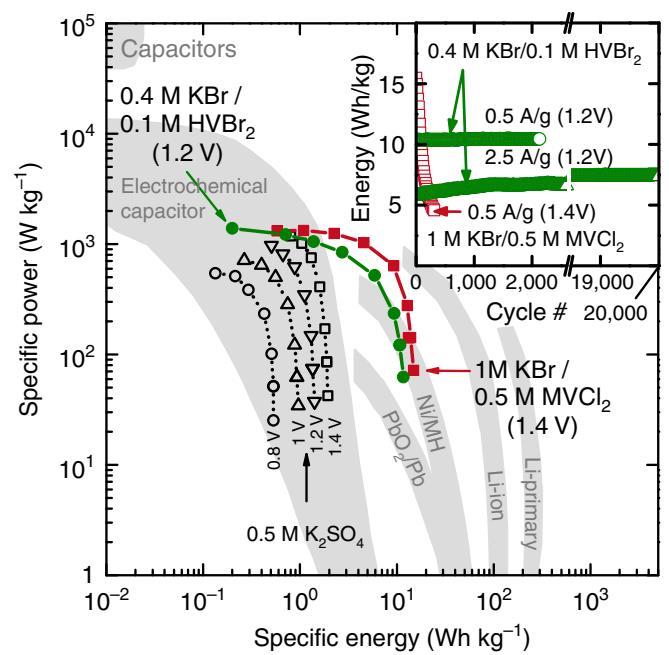

Figure 4 | Ragone plot of redox-EDLC performance from volume-limiting cells. Data for $1 \mathrm{M} \mathrm{KBr} / 0.5 \mathrm{M} \mathrm{MVCl}_{2}$ and $0.4 \mathrm{M} \mathrm{KBr} / 0.1 \mathrm{M} \mathrm{HVBr}_{2}$ electrolytes are shown in red and green, respectively, and are overlaid on the performance of various electrochemical devices from ref. 2 . The redoxEDLC performance metrics were normalized to the mass of both electrodes and electrolyte. The inset shows the long-term cycling performance of both cells obtained by galvanostatic cycling at 0.5 and $2.5 \mathrm{Ag}_{\text {dry }}^{-1}$ (every tenth cycle marked). Higher current was used to speed up the 20,000 cycle test and the $\mathrm{HV} / \mathrm{Br}$ cell showed no degradation at $0.5 \mathrm{Ag}_{\text {dry }}^{-1}$ after the 20,000 cycle test at $2.5 \mathrm{Ag}_{\text {dry }}^{-1}$.
The faradaic contribution is derived from the Nernst equation (that is, assuming fast electrode kinetics).

$$
E_{\mathrm{el}}=E^{\circ \prime}-\frac{R T}{n F} \times \ln (Q)
$$

$E_{\mathrm{el}}$ is the electrode potential, $R$ is the gas constant, $T$ is the temperature in $\mathrm{K}, n$ is the number of electrons in the half-reaction and $E^{\prime \prime}$ is the formal potential. $Q$ is the reaction quotient for the general redox half-reaction, $x \mathrm{X}+n \mathrm{e}^{-} \rightarrow y \mathrm{Y}$, and is a function of the total charge transferred through redox reactions $\left(q_{\mathrm{red}}\right)$, the initial redox-species concentration and the electrolyte volume. Combining equations yields $q_{\mathrm{red}}$ as a function of $E_{\mathrm{el}}$ (see Supplementary Note 4).

The total faradaic charge passed through the electrode $q_{\mathrm{far}}$ at a potential $E_{\mathrm{el}}$ is:

$$
q_{\mathrm{far}}=q_{\mathrm{red}}\left[E_{\mathrm{el}}\right]-q_{\mathrm{red}}\left[E_{\mathrm{el}, 0}\right]
$$

The total charge passed for an electrode is the sum of faradaic $q_{\mathrm{far}}$ and capacitive $q_{\text {cap }}$ components.

$$
q_{\mathrm{el}}=q_{\mathrm{far}}+q_{\mathrm{cap}}
$$

The complete cell operates under the constraints that the total charge passed ( $\left.q_{\text {cell }}\right)$ is equal to the charge passed at the positive $q_{\mathrm{p}}$ and negative $q_{\mathrm{n}}$ electrodes.

$$
q_{\text {cell }}=q_{\mathrm{p}}=q_{\mathrm{n}}, V_{\text {cell }}=E_{\mathrm{p}}-E_{\mathrm{n}}
$$

The above set of equations are solved numerically to generate charge-discharge profiles for the redox capacitors, as are overlaid on experimental data in Fig. 5.

Comparing the model to experimental data provides insight into device operation. The formal potential of $\mathrm{MV}^{2+} / \mathrm{MV}^{+}$(in the activated carbon) is found to be $-0.53 \mathrm{~V}$ versus SCE, less negative than the standard potential of $-0.69 \mathrm{~V}$ versus $\mathrm{SCE}^{41,43}$. From the electrochromics literature, it is known that viologen dications are reversibly reduced to form adsorbed $\left[\mathrm{V}^{+}\right]\left[\mathrm{X}^{-}\right]$ layers on the electrode at potentials less negative than the

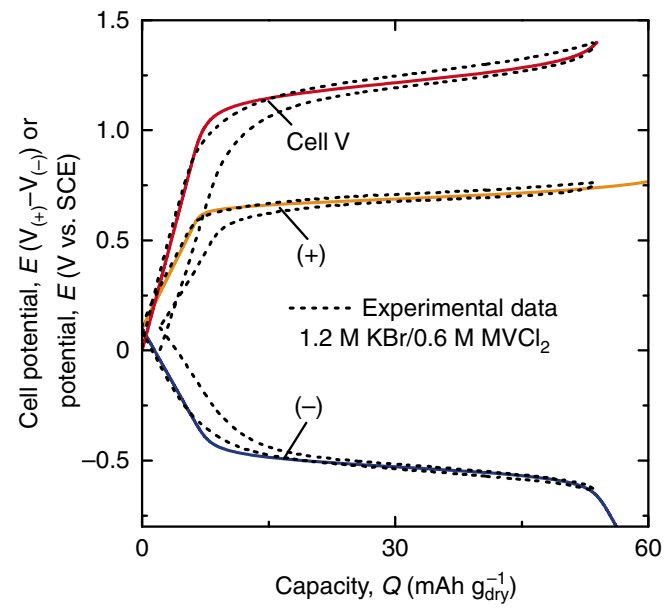

Figure 5 | Model calculations compared with experimental data for galvanostatic charge/discharge profiles. The experimental data (dashed lines) are for a $1 \mathrm{M} \mathrm{KBr} / 0.5 \mathrm{M} \mathrm{MVCl}_{2}$ (nominal) cell cycled to $1.4 \mathrm{~V}$ at $0.5 \mathrm{Ag}_{\text {dry }}^{-1}$. The experimental charge and discharge curves are overlaid to illustrate the hysteresis and coulombic efficiency of the real cell. The model parameters that best fit the experimental data are: $\mathrm{C}_{\mathrm{sp},+}=95 \mathrm{Fg}^{-1}$, $\mathrm{C}_{\mathrm{sp},-}=105 \mathrm{Fg}^{-1}, \mathrm{E}_{\mathrm{Br}_{3}^{-} / \mathrm{Br}^{-}}^{\circ}=0.70 \mathrm{~V}$ versus SCE, $\mathrm{E}_{\mathrm{MV}^{2+} / \mathrm{MV}^{+}}^{\circ}=-0.53 \mathrm{~V}$ versus $\mathrm{SCE},[\mathrm{KBr}]=1.2 \mathrm{M}$, and $\left[\mathrm{MVCl}_{2}\right]=0.6 \mathrm{M}$. All other values, such as electrode mass and dimensions, electrolyte density, free volume available to electrolyte, and $E_{\mathrm{e}, 0}$ were measured experimentally or calculated directly from experimental measurements. 
standard potential ${ }^{41,42,51,63,64}$. This precipitation of $\mathrm{HV}^{+}$with $\mathrm{Br}^{-}$is consistent with measured impedance spectra that show increased resistance after $\mathrm{HV}^{+}$adsorption (Supplementary Fig. 16). A similar mechanism occurs at the positive electrode, where the formal potential for $\mathrm{Br}^{-} / \mathrm{Br}_{3}^{-}$from the model is $0.70 \mathrm{~V}$ versus SCE, less positive than the standard potential of $0.81 \mathrm{~V}$ versus $\mathrm{SCE}^{34}$. The formal potentials obtained from the model thus indicate strong adsorption at both electrodes, consistent with the separate self-discharge and adsorption measurements described earlier.

Because the electrolyte volume and total faradaic charge passed through the cell are known, it is also possible to calculate the initial concentration of redox-active species. Electrodes soaked in $1 \mathrm{M} \mathrm{KBr} / 0.5 \mathrm{M} \mathrm{MVCl}{ }_{2}$ before cell assembly end up with an effective $\mathrm{MV}^{2+}$ concentration close to $0.6 \mathrm{M}$ and electrodes soaked in $1 \mathrm{M} \mathrm{KBr} / 0.1 \mathrm{M} \mathrm{MVCl}_{2}$ or $0.4 \mathrm{M} \mathrm{KBr} / 0.1 \mathrm{M} \mathrm{HVBr}_{2}$ end up with a viologen concentration close to 0.4 or $0.5 \mathrm{M}$. Submerging the electrodes in excess electrolyte during fabrication apparently leads to concentration of the viologen in the activated carbon due to physical adsorption, an effect observed by others ${ }^{48}$. In addition, the vacuum steps during electrolyte filling cause some electrolyte evaporation, increasing the concentration of all species by $18 \pm 8 \%$.

The agreement between experiment and simulation indicates that the redox-EDLC operates as described by the electrochemical model and that the redox couples in the solution appear to be entirely utilized. The simulation thus enables prediction of the new technology's performance limits and potential for further improvement. By adjusting variables including electrode density, which determines the free volume available for redox-active electrolyte, and the concentration of redox-active species, we calculated the performance of different cell configurations (Fig. 6). The simulations suggest that by finding a viologen with the stability of $\mathrm{HV}$ and the high solubility of $\mathrm{MV}$, a specific

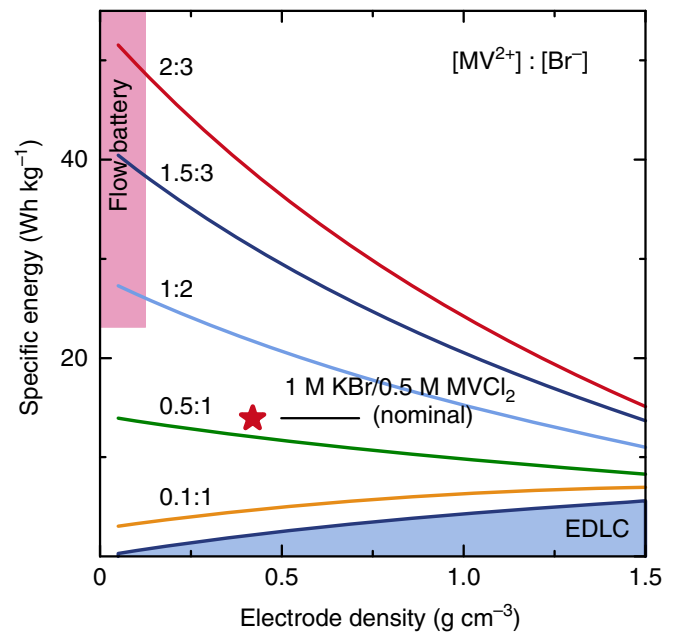

Figure 6 | Specific energy predictions using the electrochemical model for the $\mathbf{K B r} / \mathbf{M V C l}_{\mathbf{2}}$ system. The numbers indicate different concentrations (in moll ${ }^{-1}$ ) of redox-active species in the electrolyte for a range of activated carbon electrode densities. The specific energy is normalized to the mass of electrodes and electrolyte, and the specific capacitance of each electrode is modelled as $100 \mathrm{Fg}^{-1}$. For very low electrode density, the performance is determined only by the redox-active electrolyte (somewhat akin to a 'static' flow battery). Without redox-active species the pure EDLC behaviour is recovered, as indicated by the blue region at the bottom of the plot. The experimental data for the $0.5 \mathrm{M} \mathrm{MVCl}_{2} / 1 \mathrm{M} \mathrm{KBr}$ (nominal) cell with a density of $0.42 \mathrm{~g} \mathrm{~cm}^{-3}$ and capacitance of $108 \mathrm{Fg}^{-1}$ is indicated by the red star. energy two to three times higher than what is reported here is experimentally possible.

In summary, we report redox EDLCs with new viologen couples and record specific energies of $14 \mathrm{Wh} \mathrm{kg}_{\text {wet }}^{-1}(1 \mathrm{M} \mathrm{KBr} /$ $\left.0.5 \mathrm{M} \mathrm{MVCl}_{2}\right)$ and $11 \mathrm{Wh} \mathrm{kg}_{\text {wet }}^{-1}\left(0.4 \mathrm{M} \mathrm{KBr} / 0.1 \mathrm{M} \mathrm{HVBr}_{2}\right)$ when accounting for the complete electrolyte and electrode mass. As redox-active ions compose the electrolyte, the approach converts the 'dead' weight of a conventional EDLC electrolyte into an active element for charge storage. The cells use neutral-pH electrolyte, can be assembled without a dry room or glove box, and have slow self-discharge similar to commercial non-aq. cells-without the use of an ion-selective membrane separator that is needed in other systems. By studying related redox electrolytes, we showed that the slow self-discharge is due to adsorption of the charged form of the redox couples (for example, $\mathrm{Br}_{3}^{-}$and $\mathrm{MV}^{+}$or $\mathrm{HV}^{+}$) onto the activated carbon and that simple electrostatic effects were unable to prevent self-discharge. Our electrochemical model quantitatively describes the measurements and demonstrates that, with targeted design of new couples, the energy density could be further improved by a factor of 3 to near $50 \mathrm{Wh} \mathrm{kg}^{-1}$. These systems may thus find use in applications requiring energy and power performance in between that of batteries and traditional electrochemical capacitors.

\section{Methods}

Carbon electrodes. Nanoporous carbon was prepared by $\mathrm{CO}_{2}$ activation from high-purity carbon powder (Donacarbo, Osaka Gas Co.). Carbon precursor ( $1 \mathrm{~g})$ positioned in the centre of a tube furnace was heated to $890^{\circ} \mathrm{C}$ under flowing $\mathrm{CO}_{2}$ $\left(100 \mathrm{ml} \mathrm{min}^{-1}\right)$ for $22.5 \mathrm{~h}$, which resulted in burn-off of $73.2 \%$ of the carbon mass and resulted in a Brunauer-Emmett-Teller (BET) surface area of $2,470 \mathrm{~m}^{2} \mathrm{~g}^{-1}$. The methylene blue-accessible surface area is $1,620 \mathrm{~m}^{2} \mathrm{~g}^{-1}$ (Supplementary Note 5 and Supplementary Fig. 17). The elemental composition (from inductively coupled plasma analysis) and pore size distribution of the prepared activated carbon were characterized (Supplementary Table 3 and Supplementary Fig. 18). Further details of the activated carbon preparation are reported elsewhere ${ }^{65}$. Activated carbon, polytetrafluoroethylene binder and acetylene black conductive additive were mechanically mixed with a 90:5:5 weight ratio. A 10-mm-diameter electrode pellet was fabricated from $\sim 10 \mathrm{mg}\left(\sim 22 \mathrm{~m}^{2}\right.$ per pellet) of the mixture by hydraulic pressing at 2,000 psi. To enhance the wetting of the electrode, the electrode pellets were immersed in excess electrolyte under vacuum for $10 \mathrm{~min}$ (to remove the air in the void space), and then pressurized with $\mathrm{N}_{2}$ at 150 psi to force electrolyte into the pores. The process was carried out twice to ensure the electrolyte was thoroughly infiltrated.

Electrolytes. The electrolytes were prepared by either dissolving redox-reactive or electrochemically inert salts in $18.2 \mathrm{M} \Omega$ water. The salts were obtained as follows: KI (99\%, Alfa Aesar), KBr (99.999\%, Alfa Aesar), $\mathrm{MVCl}_{2}$ hydrate, $\mathrm{MVCl}_{2}$ (98\%, Sigma Aldrich), HV dibromide, $\mathrm{HVBr}_{2}$ (98\%, TCI AMERICA), $\mathrm{K}_{2} \mathrm{SO}_{4}$ (99.99\%, Alfa Aesar), $\mathrm{K}_{4}\left[\mathrm{Fe}(\mathrm{CN})_{6} \cdot 3 \mathrm{H}_{2} \mathrm{O}\right]$ (Mallinckrodt) and $\mathrm{Ru}\left(\mathrm{NH}_{3}\right)_{6} \mathrm{Cl}_{3}$ (99\%, Strem Chemicals). $\mathrm{Co}$ (bpy) ${ }_{3} \mathrm{Cl}_{2}$ was prepared by literature methods ${ }^{66}$.

Analytical electrochemistry. All electrochemical measurements were performed with a potentiostat/galvanostat (SP-300, Bio-logic). Redox-active electrolytes were first studied using a standard three-electrode configuration with a Pt or GC working electrode. Electrode discs were hand-polished for $30 \mathrm{~s}$ using $0.25 \mu \mathrm{m}$ alumina/water slurry on Buehler microcloth. The electrode was then rinsed and sonicated in $18.2 \mathrm{M} \Omega$ water for $30 \mathrm{~s}$. A coiled Pt wire and saturated calomel electrode (SCE, Fisher Scientific) served as the counter and reference, respectively. Test solutions $(10 \mathrm{ml})$ were sparged with $\mathrm{N}_{2}$ for 10 min to remove dissolved $\mathrm{O}_{2}$.

Three-electrode cell design. The cell was built from a perfluoroalkoxy (PFA) T-shaped Swagelok fitting and used insulated GC current collectors (Supplementary Fig. 1a). Between the activated carbon pellets, a paper separator (Whatman qualitative filter paper, Grade 1) was inserted to prevent direct electrical contact between electrodes. The electrodes/separators were soaked in test electrolyte (deaerated by flowing $\mathrm{N}_{2}$ gas for 10 min prior to use), and pressed in between two current-collector rods. The cell was then flooded with $0.4-0.5 \mathrm{ml}$ of excess electrolyte. The rods were made of a GC plate (3-mm thick, type 2, Alfa Aesar) bonded to a Ni (Nickel Alloy 200, McMaster) body with the sides insulated with non-conducting epoxy (Stycast 1,266, Emerson and Cuming). Before each test, the GC surface was polished as with the analytical electrochemistry. The use of GC avoids potential complications due to background corrosion of, for example, stainless-steel current collectors often used in Swagelok cells. A SCE reference 
electrode placed with the tip at the edge of the separator was incorporated to allow for independent measurement of the absolute potential at each electrode (Supplementary Fig. 1). The cell exterior was purged with wet $\mathrm{N}_{2}$ during voltammetry and constant-current charge/discharge cycling.

Cell design for specific energy and power measurements. An 11.3-mm-wide cylindrical chamber machined from inert plastic (Kel-F) served as the cell housing (Supplementary Fig. 1b). Two GC discs tightly fit with o-ring seals and backcontacted with $\mathrm{Cu}$ wire served as the current collectors. The separator (Polycarbonate membrane filter, STERLITECH) was cut into a disc with an identical diameter as the chamber. The electrodes were $10-\mathrm{mm}$-diameter pellets, fabricated as described above.

Control/comparison devices. Commercial electrochemical capacitors were tested to provide reference self-discharge and performance data (Supplementary Fig. 11). One capacitor utilizes organic electrolyte with a specified $2.7 \mathrm{~V}$ of working potential range (BACP0010 P270 T01, Maxwell Technologies). The other (CLG03P025L12, Cellergy) utilizes aq. electrolyte, and the operating potential is specified at $3.5 \mathrm{~V}$ (presumably obtained using at least three cells in series).

Reproducibility. All EDLC measurements were reproduced at least three times, with the exception of the long-term cycling studies and $24 \mathrm{~h}$ self-discharge tests. Representative data are shown in all cases.

\section{References}

1. Conway, B. E. Electrochemical Supercapacitors: Scientific Fundamentals and Technological Applications (Springer, 1999).

2. Simon, P. \& Gogotsi, Y. Materials for electrochemical capacitors. Nat. Mater. 7, 845-854 (2008).

3. Beguin, F. \& Frackowiak, E. Carbons for Electrochemical Energy Storage and Conversion Systems (Taylor \& Francis, 2009).

4. Lu, M., Beguin, F. \& Frackowiak, E. Supercapacitors: Materials, Systems and Applications (Wiley, 2013)

5. Miller, J. R. \& Simon, P. Electrochemical capacitors for energy management. Science 321, 651-652 (2008)

6. Miller, J. R. \& Burke, A. F. Electrochemical capacitors: challenges and opportunities for real-world applications. Electrochem. Soc. Interf. 17, 53-57 (2008).

7. Winter, M. \& Brodd, R. J. What are batteries, fuel cells, and supercapacitors? Chem. Rev. 104, 4245-4270 (2004).

8. Zhang, L. L. \& Zhao, X. S. Carbon-based materials as supercapacitor electrodes. Chem. Soc. Rev. 38, 2520-2531 (2009).

9. van Schalkwijk, W. \& Scrosati, B. Advances in Lithium-Ion Batteries (Springer, 2002).

10. Huggins, R. Advanced Batteries: Materials Science Aspects (Springer, 2008).

11. Reddy, T. Linden's Handbook of Batteries 4th edn (McGraw-Hill Education, 2010)

12. Weinstein, L. \& Dash, R. Supercapacitor carbons. Mater. Today 16, 356-357 (2013).

13. Gogotsi, Y. \& Simon, P. True performance metrics in electrochemical energy storage. Science 334, 917-918 (2011)

14. Merrill, M. D. et al. Optimizing supercapacitor electrode density: achieving the energy of organic electrolytes with the power of aqueous electrolytes. RSC $A d v$. 4, 42942-42946 (2014).

15. Amatucci, G. G., Badway, F., Du Pasquier, A. \& Zheng, T. An asymmetric hybrid nonaqueous energy storage cell. J. Electrochem. Soc. 148, A930-A939 (2001).

16. Long, J. W. et al. Asymmetric electrochemical capacitors-Stretching the limits of aqueous electrolytes. MRS Bull. 36, 513-522 (2011).

17. Augustyn, V. et al. High-rate electrochemical energy storage through $\mathrm{Li}^{+}$ intercalation pseudocapacitance. Nat. Mater. 12, 518-522 (2013).

18. Vonlanthen, D., Lazarev, P., See, K. A., Wudl, F. \& Heeger, A. J. A stable polyaniline-benzoquinone-hydroquinone supercapacitor. Adv. Mater. 26, 5095-5100 (2014).

19. Lota, G., Fic, K. \& Frackowiak, E. Alkali metal iodide/carbon interface as a source of pseudocapacitance. Electrochem. Commun. 13, 38-41 (2011).

20. Roldán, S., Blanco, C., Granda, M., Menéndez, R. \& Santamaría, R. Towards a further generation of high-energy carbon-based capacitors by using redoxactive electrolytes. Angew. Chem. Int. Ed. 50, 1699-1701 (2011).

21. Frackowiak, E., Fic, K., Meller, M. \& Lota, G. Electrochemistry serving people and nature: high-energy ecocapacitors based on redox-active electrolytes. ChemSusChem 5, 1181-1185 (2012).

22. Senthilkumar, S. T., Selvan, R. K. \& Melo, J. S. Redox additive/active electrolytes: a novel approach to enhance the performance of supercapacitors. J. Mater. Chem. A 1, 12386-12394 (2013).

23. Chen, L., Bai, H., Huang, Z. \& Li, L. Mechanism investigation and suppression of self-discharge in active electrolyte enhanced supercapacitors. Energy Environ. Sci. 7, 1750-1759 (2014).
24. Mai, L.-Q. et al. Synergistic interaction between redox-active electrolyte and binder-free functionalized carbon for ultrahigh supercapacitor performance. Nat. Commun. 4, 2923 (2013).

25. Wang, B. et al. A hybrid redox-supercapacitor system with anionic catholyte and cationic anolyte. J. Electrochem. Soc. 161, A1090-A1093 (2014).

26. Liu, C., Yu, Z., Neff, D., Zhamu, A. \& Jang, B. Z. Graphene-based supercapacitor with an ultrahigh energy density. Nano Lett. 10, 4863-4868 (2010).

27. Zhang, L. et al. High-performance supercapacitor electrode materials prepared from various pollens. Small 9, 1342-1347 (2013).

28. Gao, Q., Demarconnay, L., Raymundo-Pinero, E. \& Beguin, F. Exploring the large voltage range of carbon/carbon supercapacitors in aqueous lithium sulfate electrolyte. Energy Environ. Sci. 5, $9611-9617$ (2012).

29. Zhu, Y. et al. Carbon-based supercapacitors produced by activation of graphene. Science 332, 1537-1541 (2011).

30. Xu, Y. et al. Holey graphene frameworks for highly efficient capacitive energy storage. Nat. Commun. 5, 4554 (2014).

31. Yu, D. et al. Scalable synthesis of hierarchically structured carbon nanotubegraphene fibres for capacitive energy storage. Nat. Nanotechnol. 9, 555-562 (2014).

32. Hiegel, G. A., Abdala, M. H., Burke, S. V. \& Beard, D. P. Methods for preparing aqueous solutions of chlorine and bromine for halogen displacement reactions. J. Chem. Educ. 64, 156 (1987).

33. Goldstein, S. W. The iodide-iodine solubility relation. J. Am. Pharm. Assoc. 41, 333-335 (1952)

34. Bard, A. J., Parsons, R. \& Jordan, J. Standard Potentials in Aqueous Solution (Taylor \& Francis, 1985).

35. Andreas, H. A., Lussier, K. \& Oickle, A. M. Effect of Fe-contamination on rate of self-discharge in carbon-based aqueous electrochemical capacitors. J. Power Sources 187, 275-283 (2009).

36. Lewandowski, A., Jakobczyk, P., Galinski, M. \& Biegun, M. Self-discharge of electrochemical double layer capacitors. Phys. Chem. Chem. Phys. 15, 8692-8699 (2013).

37. Weber, A. et al. Redox flow batteries: a review. J. Appl. Electrochem. 41, 1137-1164 (2011).

38. Faita, G., Fiori, G. \& Mussini, T. Electrochemical processes of the bromine/ bromide system. Electrochim. Acta 13, 1765-1772 (1968).

39. Mastragostino, M. \& Gramellini, C. Kinetic study of the electrochemical processes of the bromine/bromine aqueous system on vitreous carbon electrodes. Electrochim. Acta 30, 373-380 (1985).

40. Michaelis, L. \& Hill, E. S. The viologen indicators. J. Gen. Physiol. 16, 859-873 (1933).

41. Bird, C. L. \& Kuhn, A. T. Electrochemistry of the viologens. Chem. Soc. Rev. 10, 49-82 (1981).

42. van Dam, H. T. \& Ponjeé, J. J. Electrochemically generated colored films of insoluble viologen radical compounds. J. Electrochem. Soc. 121, 1555-1558 (1974).

43. Monk, P. M. S. The Viologens: Physicochemical Properties, Synthesis, and Applications of the Salts of 4,4'-Bipyridine (Wiley, 1998).

44. Yang, H.-H. \& McCreery, R. L. Effects of surface monolayers on the electrontransfer kinetics and adsorption of methyl viologen and phenothiazine derivatives on glassy carbon electrodes. Anal. Chem. 71, 4081-4087 (1999).

45. Monk, P., Mortimer, R. \& Rosseinsky, D. Electrochromism and Electrochromic Devices (Cambridge Univ. Press, 2007).

46. Ito, M. \& Kuwana, T. Spectroelectrochemical study of indirect reduction of triphosphopyridine nucleotide: I. Methyl viologen, ferredoxin-TPN-reductase and TPN. J. Electroanal. Chem. Interf. 32, 415-425 (1971).

47. Deloitte Access Economics. The Economic Impact of Paraquat (Syngenta Australia Pty Ltd, 2013).

48. Nakamura, T. et al. Adsorption removal of paraquat and diquat onto activated carbon at different adsorption temperature. Toxicol. Environ. Chem. 70, 275-280 (1999).

49. Bard, A. J. \& Faulkner, L. R. Electrochemical Methods: Fundamentals and Applications 2nd edn (Wiley Global Education, 2000).

50. Datta, M., Jansson, R. E. \& Freeman, J. J. In situ resonance raman spectroscopic characterization of electrogenerated methyl viologen radical cation on carbon electrode. Appl. Spectrosc. 40, 251-258 (1986).

51. Lezna, R. O. \& Centeno, S. A. Spectroelectrochemistry of methyl viologen/ iodide solutions at mercury film electrodes. Langmuir 12, 4905-4908 (1996).

52. Bewick, A., Lowe, A. C. \& Wederell, C. W. Recrystallisation process in viologen-based electrochromic deposits: voltammetry coupled with rapid timeresolved spectroscopy. Electrochim. Acta 28, 1899-1902 (1983).

53. Compton, R. G., Waller, A. M., Monk, P. M. S. \& Rosseinsky, D. R. Electron paramagnetic resonance spectroscopy of electrodeposited species from solutions of 1,1'-bis-(p-cyanophenyl)-4,4'-bipyridilium (cyanophenyl paraquat, CPQ). J. Chem. Soc. Faraday Trans. 86, 2583-2586 (1990).

54. Rosseinsky, D. R., Monk, P. M. S. \& Hann, R. A. Anion-dependent aqueous electrodeposition of electrochromic 1,1'-bis-cyanophenyl-4,4'-bipyridilium 
(cyanophenylparaquat) radical cation by cyclic voltammetry and spectroelectrochemical studies. Electrochim. Acta 35, 1113-1123 (1990).

55. Rosseinsky, D. R. \& Monk, P. M. S. Electrochromic cyanophenylparaquat (CPQ: 1,1'-bis-cyanophenyl-4,4'-bipyridilium) studied voltammetrically, spectroelectrochemically and by ESR. Sol. Energ. Mater. Sol. Cells 25, 201-210 (1992).

56. Milne, G. W. A. Gardner's Commercially Important Chemicals: Synonyms, Trade Names, and Properties (Wiley, 2005).

57. Wardman, P. Reduction potentials of one-electron couples involving free radicals in aqueous solution. J. Phys. Chem. Ref. Data 18, 1637-1755 (1989).

58. Lieder, M. \& Schläfer, C. W. Synthesis and electrochemical properties of new viologen polymers. J. Appl. Electrochem. 27, 235-239 (1997).

59. Roldán, S., Granda, M., Menéndez, R., Santamaría, R. \& Blanco, C. Supercapacitor modified with methylene blue as redox active electrolyte. Electrochim. Acta 83, 241-246 (2012).

60. Senthilkumar, S. T., Selvan, R. K., Ponpandian, N., Melo, J. S. \& Lee, Y. S. Improved performance of electric double layer capacitor using redox additive $\left(\mathrm{VO}^{2+} / \mathrm{VO}_{2}^{+}\right)$aqueous electrolyte. J. Mater. Chem. A 1, 7913-7919 (2013).

61. Park, J., Kim, B., Yoo, Y.-E., Chung, H. \& Kim, W. Energy-density enhancement of carbon-nanotube-based supercapacitors with redox couple in organic electrolyte. ACS Appl. Mater. Interf. 6, 19499-19503 (2014).

62. Huskinson, B. et al. A metal-free organic-inorganic aqueous flow battery. Nature 505, 195-198 (2014).

63. Heyrovsky, M \& Novotny, L. Interfacial interactions and the heterogeneous one-electron reduction of methyl viologen. Collect. Czech. Chem. Commun. 52, 1097-1114 (1987)

64. Sagara, T., Fujihara, Y. \& Tada, T. Molecular structure dependence of the phase transition spike response of viologens at an HOPG electrode using bisviologen and carboxylated viologen. J. Electrochem. Soc. 152, E239-E246 (2005).

65. Maciá-Agulló, J. A., Moore, B. C., Cazorla-Amorós, D. \& Linares-Solano, A. Activation of coal tar pitch carbon fibres: Physical activation vs. chemical activation. Carbon 42, 1367-1370 (2004).

66. Sapp, S. A., Elliott, C. M., Contado, C., Caramori, S. \& Bignozzi, C. A Substituted polypyridine complexes of cobalt(II/III) as efficient electrontransfer mediators in dye-sensitized solar cells. J. Am. Chem. Soc. 124, 11215-11222 (2002).

67. Jasinski, R. J. The electrochemistry of some n-heptylviologen salt solutions, J. Electrochem. Soc. 124, 637-641 (1977).

68. Schweitzer, G. K. \& Pesterfield, L. L. The Aqueous Chemistry of the Elements (Oxford Univ. Press, 2009).
69. Skyllas-Kazacos, M. \& Milne, N. Evaluation of iodide and titanium halide redox couple combinations for common electrolyte redox flow cell systems. J. Appl. Electrochem. 41, 1233-1243 (2011).

70. Licht, S. \& Davis, J. Disproportionation of aqueous sulfur and sulfide: kinetics of polysulfide decomposition. J. Phys. Chem. B 101, 2540-2545 (1997).

\section{Acknowledgements}

This work was supported by Advanced Research Projects Agency-Energy (ARPA-E), Department of Energy (DOE) of the United States (Award No. DE-AR0000344). D.V. acknowledges support from BioSolar Incorporation and the Swiss National Science Foundation (SNF-PBBSP2-144291). S.W.B. acknowledges support from the Research Corporation for Science Advancement as a Cottrell Scholar.

\section{Author contributions}

S.-E.C. and S.W.B. designed and executed the experiments, analysed the data and wrote the manuscript. B.E. and S.W.B. developed the electrochemical model. X.W. and X.J. synthesized and characterized the activated carbon. B.E., D.V., X.J. and G.D.S. contributed to experiment planning, data analysis, and manuscript preparation and revision.

\section{Additional information}

Supplementary Information accompanies this paper at http://www.nature.com/ naturecommunications

Competing financial interests: The authors declare no competing financial interests.

Reprints and permission information is available online at http://npg.nature.com/ reprintsandpermissions/

How to cite this article: Chun, S-E. et al. Design of aqueous redox-enhanced electrochemical capacitors with high specific energies and slow self-discharge. Nat. Commun. 6:7818 doi: $10.1038 /$ ncomms8818 (2015).

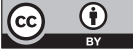

This work is licensed under a Creative Commons Attribution 4.0 International License. The images or other third party material in this article are included in the article's Creative Commons license, unless indicated otherwise in the credit line; if the material is not included under the Creative Commons license, users will need to obtain permission from the license holder to reproduce the material To view a copy of this license, visit http://creativecommons.org/licenses/by/4.0/ 